\title{
The Significance of Non-traditional and Alternative Assessment in English Language Teaching: Evidence From Literature
}

\author{
Mazin Mansory \\ English Language Institute (ELI), King Abdulaziz University (KAU), Jeddah, Saudi Arabia \\ E-mail: mmmansory@kau.edu.sa
}

Received: September 5, 2020 Accepted: October 18, 2020 Published: October 25, 2020

doi:10.5296/ijl.v12i5.17782

URL: https://doi.org/10.5296/ijl.v12i5.17782

\begin{abstract}
Assessment is an integral part of teaching and learning in educational organizations that requires teachers to prepare tests in order to evaluate their learners' performance. In language teaching contexts, traditional assessment often evaluates learners' knowledge of previously learned language items. It is a mandatory process that determines the progress of language learners and the effectiveness of teaching/learning materials. This theoretical article reviews the literature on the notion of traditional assessment or static assessment which has certain shortcomings. Owing to the various drawbacks of static assessment, the review of related literature on the topic highlights and proposes alternative assessment methods, such as authentic assessment, dynamic assessment, peer assessment, and self-assessment. In contrast to traditional assessment, these different forms of alternative assessment share a common purpose that is to provide language learners with an opportunity to reflect on their strengths and weaknesses and set their future learning goals. The most common of the assessment methods that encourage learners' reflection were peer assessment and self-assessment which involve learners to assess their own progress as well as engage with peers in classrooms to give each other feedback on their language learning tasks assigned by teachers. The studies reviewed in this article illustrate that alternative assessment methods in the form of peer and self-assessment have a positive influence on the language learners' performance and their learning outcomes.
\end{abstract}

Keywords: Authentic assessment, Alternative assessment, EFL context, Evaluation, Peer assessment, Self-assessment, Testing 


\section{Introduction}

Teachers around the world find it a challenging task to assess their learners in a classroom environment. It is not a smooth process to assess learners as teachers, in general, perceive it differently based on their academic, professional and contextual understanding of assessment. It might vary from teacher to teacher or context to context; however, we can safely put it that it is a mandatory part of teaching and learning since evaluation is always important to see and determine the progress of second or foreign language learners. As an integral part of learning, "evaluation is not restricted to the context of education; it is part of our everyday lives" (Dickins \& Germaine. 1992, p: 3), and we evaluate and assess our daily actions and day-to-day activities to understand how we can improve ourselves. This can be applied to the context of language teaching and learning as well. As language learners are given a different language point to learn and practice in a classroom environment, it becomes essential for teachers to test learners on previously taught language points, assess their progress, identify their strengths and weaknesses in order to plan, modify and adjust the teaching method and material accordingly. However, in most cases, teachers have an exam-oriented and teacher-oriented culture in which students are often ignored and learners are tested to determine their next level. This is perceived as a traditional way of assessing language learners who do not achieve the full potential of the learners. Therefore, the literature suggests alternative ways of assessment, such as self-assessment, dynamic assessment, peer assessment, and authentic assessment.

Traditional assessment is usually considered a mandatory tool of evaluation that is imposed on teachers and learners to follow a certain set of procedures. This sort of evaluation often lacks learners' and teachers' voice in the procedure which leads to inappropriate and unsuitable forms of evaluation (Mastuno, 2009). Since traditional assessment has been widely criticized for its shortcomings, alternative assessment in the form of authentic assessment, dynamic assessment, self-assessment, portfolio assessment, performance assessment, and peer assessment have been introduced and promulgated by scholars (Chen, 2008; HuertaMacias, 1995).

As the role of assessment is widely acknowledged in educational contexts around the world, this conceptual paper takes into consideration the meaning and significance of assessment and its various types that are considered alternative to traditional assessment. This paper also reviews the literature on the significance of alternative assessment tools in the field of English language teaching (ELT) and more specifically in English as a foreign language (EFL) context.

\section{The Meaning of Assessment}

In general, assessment is a time-consuming process that is aimed at understanding and improving the students' learning progress (Cowie \& Bell, 1999). Assessment is an integral part of the educational system and it plays a pivotal role in learning and teaching (Pierce, 2002; cited in Kırmızı \& Kömeç, 2016). The process of assessment informs instructional decisions related to curriculum and syllabus and assists teachers and students to diagnose learners' strengths and weaknesses related to classroom teaching and learning. When students 
receive feedback on their performance, it gives them a chance to reflect on their strengths and weaknesses and plan their learning accordingly. Moreover, teachers also customize and supplement their teaching materials and activities according to the learning needs of the students.

Assessment has been seen as a process of collecting information about learners' performance to understand and determine their existing level of knowledge (Baily, 1996; McNamara, 2004). In educational contexts around the world, it is a common practice to evaluate and measure students' actual level of development and see what they have learned and what they need to further improve on. This common practice of assessment is called static assessment (Feuerstein et al., 1979), which is more of a traditional evaluative nature. Researchers advocate that learners often fail to develop owing to static assessment which results in students' as well as teachers' lack of motivation affecting the pedagogical process in classrooms. Poehner (2008) highlighted this issue from teachers' perspective who perceived it "distinct from, and perhaps even at odds with, the goals of teaching" (p. 4). This static assessment not only contradicts the teaching goals, but it also forces teachers to prepare students for the tests at the cost of learning. This problem is apparent in the field of English language teaching too as Poehmer (2008) states that "language assessment and pedagogy have emerged as distinct subfields with their own professional journals and meetings" (p. 4). Ideally, the learners' knowledge should be tested frequently, and tests should serve as a tool for learning in the language teaching context.

Static assessment is a traditional way of measuring learners' performances, which does not enable the assessors to work on the learners' weaknesses and improve them. In a conducive learning milieu, it can be assumed that tests do not assess the learners' ability to learn, rather they help them to show their existing level of knowledge and connect it to their future learning goals. Literature shows that a paradigm shift is required, and we need to move from static assessment to dynamic assessment (Kozulin \& Garb, 2002; Poehner, 2008) in order to enhance teaching and learning outcomes. The dynamic assessment looks into assessment of learners from a different perspective. It is mainly a collaboration between teachers and students which aims to identify learners' problems, the causes of the problems, and assist them to overcome their learning problems.

\section{Alternative Assessments}

Richards and Renandya (2002) state that alternative assessment is an alternative approach to standardized testing and all the issues related to traditional testing and evaluation. Looking at the shortcomings of the traditional and static assessment tools, English language teachers, test designers and test administrators have reached a consensus that they need to adopt new and alternative assessments tools, methods and strategies in a bid to effectively monitor learners' progress and cater to the learning needs of the English language learners. The alternative way of assessment will have a goal to undertake tasks and measure learners' proficiency in a real-life situation. The new assessment tools can have the element of surprise, competition, enjoyment and fun. Using authentic and different non-traditional tools, teachers can opt for projects, concept maps, performance assignments, peer assessment, self-assessment, portfolio 
assessment, observation, drama, journals, diagnostic tree, teacher and student interviews, and posters (An1l \& Acar, 2008; Büyüktokatlı \& Bayraktar, 2014). These alternative assessment tools provide learners with opportunities to integrate and produce various aspects of language. In addition, teachers can reflect on teaching contents and make them more suitable to the learners' needs. Since the information teachers collect are based on real-life situations, students do not focus on recalling and reproducing the language items; rather, focus on producing authentic language in a given situation. As alternative assessment consisted of spontaneous and real-life tasks, students develop and improve their reflective, problem solving and decision-making skills (Brualdi, 1996).

Classroom assessment is mainly focused on giving continuous feedback to the learners that optimizes the learning outcomes of the students. It is important to mention that classroom feedback should bring positivity and encouragement to learners, so they feel that assessment is not for grades, but it is to improve and develop their language skills. This approach will help teachers to reduce learner anxiety about assessment and give them a model of assessment that is different to a traditional one. As it is well known, traditional assessment often checks students' performances related to recently taught material via tools, such as multiple-choice questions, cloze tests, and test questions, this performance-oriented test can be useful to determine students' short-term learning goals; however, it may not effective in setting and achieving long term objectives. In order to make language learning a long-term plan for the students and create an anxiety-free classroom environment, teachers need to make sure that learners remain highly motivated before, while and after the test. To achieve that, language teachers should have knowledge about the different types of assessment to collect data with an aim of recognizing students' problems.

In a language classroom, assessment involves knowing about learners' awareness, their understanding of language items, their attitude to language learning and their perceptions of language. Through assessment, teachers come to know about the learners' learning needs which are extremely pivotal to successful teaching. Planning lessons can be influenced by the process of assessment, therefore, if assessment tools do not yield valid results teaching goals may not be realized (Brown \& Abeywickrama, 2010; Sarıçoban, 2011).

\section{The Significance of Alternative Assessment}

Assessment is the key part of classroom learning and teaching which involves methods and techniques to collect information about learners' understanding, knowledge and motivation (Allan, 1999; Ekbatani \& Pierson, 2000; Lambert \& Lines, 2000) and make informed decisions. Assessment plays a key role to know whether organizational goals have been achieved and the learners' grades reflect their linguistic ability. Without assessment, teachers and educators cannot determine the proficiency, s, ills and knowledge of language learners (Taras, 2005). Once the students are aware of their strengths and weaknesses, it motivates and encourages them to design their plan and overcome language-related problems (Wojtczak, 2002). Moreover, students receive constructive and valuable feedback on their learning acquisition and teachers can use that information to make decisions related to content material (Taras, 2005; Stiggins, 1992). 
Assessment is undoubtedly an important part of education systems, however, in the EFL learning and teaching contexts it is highly valued and performed in various forms. The organizational objectives of EFL institutes are often written and linked to the learning progress of the students, therefore, assessment enables the management to see if the learning objectives are achieved or not. This valuable information can influence administrative decisions, pedagogical practices and teaching materials.

Teachers and administrators have different options to analyze students' performance through different assessment formats (Black \& William, 1998; Wang, Wang, Wang, \& Huang, 2006; Watering, Gijbels, Dochy, \& Rijt, 2008). As testing, evaluation and assessment are sources of anxiety, stress and burnout for students, they might also trigger negative feelings, perceptions and memories resulting in under- or poor performances (Berry, 2010). It is therefore recommended to create a test meets meet the learners' expectation and does not challenge the learners' level of understanding. More importantly, teachers may think out of the box and develop tests using alternative ways of assessment in order to create a comfortable learning environment in classrooms. If alternative ways are not developed and implemented, learners can lose interest in language learning and teaching, thus spoiling the whole purpose of the language program.

\section{The Authentic Assessment}

Authentic assessment was introduced by O'Malley and Pierce (1996) which assesses and shows that learners' development, achievement and their attitudes toward learning and teaching in classroom environment. This kind of assessment involves activities that take place in classroom. For example, portfolio assessment, self-assessment by the students and performance assessment. These activities are often integrated into teaching framework and applied in a way that triggers learners' interest in pedagogical process, as a result, their learning outcomes are positively influenced.

Authentic assessment has been seen as a great way of enhancing reading and writing skills of native English learners (e.g. French, 2003; Montgomery, 2002; Valeri-Gold et al., 1992). It is also considered an effective tool for English language learners (ELLs) (DelliCarpini, 2009; Murphy, 2009; Lenski et al., 2006), and EFL learners (Geeslin, 2003). The meta-analysis by French (2003) suggests that authentic assessment helps teachers to assess language learners' reading skills which is used as an alternative way of assessment to collect information about learners' progress in reading. In an identical review of literature, Geeslin (2003) also acknowledged its relevance in Spanish EFL context. Similarly, Montgomery (2002) found the application of authentic assessment as a useful way of recording and assessing learners' progress in reading comprehension. Moreover, DelliCarpini (2009) has highlighted its relevance with respect to teaching and developing the literacy of English language learners as authentic assessment is a tool to collect precise information about the language learners' development of English language proficiency.

Literature sample empirical evidence that highlights the significance and relevance of authentic assessment in language teaching contexts. Studies that support authentic assessment mainly consider its application as an alternative assessment to standardized assessment tools 
(DelliCarpini, 2009; French, 2003). As its usefulness is widely cited, it can be noticed that authentic assessment can contribute to language learners' language proficiency (French, 2003; Montgomery, 2002; Valeri-Gold et al., 1992). However, there is a dearth of empirical evidence on the effectiveness of authentic assessment in EFL contexts in general and Saudi EFL context in particular, as standardized testing is still a dominating practice in this part of the world.

\section{Dynamic Assessment}

Dynamic assessment is not a traditional way of measuring learners' performance. In other words, we should consider assessment as part of instruction and not apart from it (Popham, 1997), and this is not possible in a context where traditional assessment methods prevail. In traditional assessment, teachers have to be neutral; however, in dynamic assessment, teachers cannot play a neutral role and they have to mediate and collaborate with learners in order to "find routes to move the learner to the next level of development" (Haywood \& Lidz, 2007, p. 41). Unlike static assessment, teachers can engage with learners if they require guidance to improve on their weaknesses. Hence, it can be inferred that dynamic assessment is not simply a way of assessment, it can be seen as a tool to bring about difference in the learners' skills and find out the learners' potential and their ability of undertaking various tasks (Lidz \& Elliott (2000).

In the field of English language teaching, dynamic assessment has been widely investigated (Leung, 2007). Studies by Poehner's (2007) and Lin's (2010) mainly explored the influence of dynamic assessment on the learners' use of grammar in relation to narration. In these studies, the core of the dynamic assessment was included, and teachers acted as mediators and collaborators. Through dynamic assessment, learners were able to identify their problems and work with their teachers to work on their improvement.

\section{Peer Assessment}

As part of alternative assessment, peer assessment is a widely used assessment methods is different educational contexts. Peer assessment is "an arrangement for learners to consider and specify the level, value or quality of a product or performance of other equal status learners" (Topping (2009, p. 20). According to Falchikov and Goldfinch (2000), in the process of peer assessment, students "are engaging with criteria and standards" (p. 287) that enables them to a judgment about their peers' work in pair or in groups. This engaging practice of peer assessment is a learning opportunity for students as they give feedback to each other, suggest changes and correct mistakes in their oral presentations, writings, test performance and portfolios (Topping, 2009).

Literature shows that peer assessment has been influenced by different theories, such as social constructionism, andragogy and the theory of active learning (Falchikov \& Goldfinch 2000). These theories have shaped the design, structure and formation of peer assessment tools. Topping (2003, p. 65) has mentioned different ways that can be used to vary and apply peer assessment. 
a) Peer assessment can be used in a wide range of different subjects and thus, the product or output can vary (e.g. portfolios, oral presentations, writing, test performance etc);

b) Peer assessment can be formative or summative.

c) The organization of the assessors can be different (e.g. individual assessors, assessors in pairs or groups);

d) Assesses and assessors may belong to the same or different year of study and be of the same or different ability.

e) The directionality can vary as peer assessment can be one-way, mutual or reciprocal.

f) Place and time can vary as peer assessment can occur formally in class, or informally out of class.

g) The objectives of using peer assessment may vary. (Topping, 2003, p. 65)

Literature indicates that peer assessment compared to other forms of traditional assessment has a number of advantages for students (Topping 2003, 2009; Falchikov 2005; Butt 2010; Douglas 2010; Sebba et al., 2008). As an interactive activity, the first and foremost objective is "to provide feedback to learners" (Topping, 2009, p. 22). This feedback session involves getting feedback from teachers and giving feedback to peers. While giving feedback to each other, students are reminded to keep the objectives of the work in mind. The pre-determined criteria help them ve a constructive feedback to each other. As this is a rigorous process of reflecting upon each other mistakes, strengths and areas that need development, students raise awareness of their learning goals and learn to apply the criteria judgment to see the quality of learning and acquire knowledge (Douglas, 2010). Moreover, increased engagement with other learners and learning goals, students often become responsible learners who not only think about their own learning but focus on the learning of other students (Sebba et al., 2008). Since it involves learners to assess the work of other learners, peer assessment leaves a positive impact on the learners' effort of self-assessment (Butt 2010: 83). Maiz Arevalo (2008) concludes that the practice of peer assessment enables students to "assess themselves in their future performances" (p. 128).

In EFL contexts, peer assessment has attracted researchers to investigate its impact on learners' English language proficiency. Although the topic is not new to EFL settings, fewer studies have focused on investigating the influence of peer assessment on learners' performance in EFL contexts. Topping (2003) used this technique to understand the effect of peer assessment on the learners' writing tasks. As it involves giving feedback to overcome possible weaknesses, it can focus on the whole writing piece as well as the process of writing, such as editing, modifying and improving ideas and structures. Topping (2003) maintains that learners can improve a great deal when they peer assess each other writing tasks. He believes that "peer assessment seems to be at least as efficient formative terms as teacher assessment, and sometimes more effective" (Topping 2003, p. 76).

Similarly, Jahin (2012) examined the influence of peer reviewing on EFL essay writing and established a positive effect on the learners' ability to write well. The findings also suggest 
that learners were in a comfortable situation and they did not have exam anxiety. In a similar study, Birjandi and Siyyari (2010) found the positive influence of peer assessment on EFL learners' writing skills.

Apart from the writing skills, studies also show that peer assessment can positively affect EFL learners' speaking skills. Researchers examined EFL learners' oral presentations to measure their speaking skills and their attitude to speaking. For example, Nakamura (2002), Cheng and Warren (2005), and White (2009) established that peer assessment was a useful tool to improve the EFL learners' oral skills in different EFL contexts. Similarly, Falchikov (2005) found that students engaging in oral presentations and assessing each other oral presentations lead to improved speaking skills of their students.

\section{Self-assessment}

Self-assessment is "the ability to recognize good work as such, and to correct one's performance so that better work is produced" (Claxton,1995, p. 339). It is "the ability to assess one's work" (Paris \& Paris, 2001, p. 96). According to Richards and Schmidt (1985), self-assessment is "checking one's own performance on a language learning task after it has been completed or checking one's own success in using a language... [It] is an example of a metacognitive strategy in language learning" (p. 475). El Jawhari (1988) considers self-assessment as the language learning ability of learners to see their actual performances and evaluate the effectiveness of the procedure while focusing on the practice of four language skills. Self-assessment provides learners opportunities to assess their own learning progress (Blanche \& Merino, 1989). As a learner-centered approach requires techniques that engage students in classroom activities, self-assessment becomes an important tool for teachers to encourage and train students on self-assessment.

As opposed to traditional and static methods of assessment, self-assessment is deemed as an alternative way of assessment which encompasses "various types of assessment procedures that are seen as alternatives or complements to traditional standardized testing...Procedures used in alternative assessment include self- assessment, peer assessment, portfolios, learner diaries or journals, student-teacher conferences, interviews, and observation" (Richards \& Schmidt, 1985, p. 23). One of the key qualities of self-assessment is that it involves reflection which is a great way of learning and developing various skills, particularly, in language learning contexts, it adds to the learners' achievement, self-efficacy, autonomy and motivation.

Self-assessment can yield various advantages for learners and teachers. According to Aeginitou et al. (2007), it has six benefits: a) It can help teachers to monitor the progress of the learners; b) teachers can encourage students to take responsibility for their own learning; c) students and teachers can set future goals and steer their teaching and learning accordingly; d) learners can construct and reconstruct knowledge; e) teachers can promote critical thinking; and f) teachers can manage to fill the gap between high achieving and low achieving students. Similarly, Tan (2008) has found that self-assessment can lead to learners' lifelong learning in higher education. 
Self-assessment has been widely investigated to determine its effects on learners' language proficiency (e.g. Matsuno, 2009; Birjandi and Siyyari, 2010; Srichanyachon, 2011; Larsari, 2012). Dickinson (1987) has pointed out that self-assessment can lead to achieving significant educational objectives as it develops learners' autonomy and reduces teachers' burden of evaluation.

A plethora of studies has shown the usefulness of self-assessment (Black \& William, 1998; Gardner, 1999; Wei \& Chen, 2004; Coronado-Aliegro, 2006; Zavistanavičienė et al., 2006; Kavaliauskienè, 2007; Martin, 2008;). These researchers underline the importance of self-assessment as the part of formative assessment which can produce more pertinent results; however, the goals of the assessment need to be clearly defined at the outset. Moreover, to optimize the maximum potential of learners, it is very important to train students on various aspects of self-assessment and familiarize with the procedures. This will enable them set and achieve their goals in a much better way.

To further underscore its significant impact on the learners' sense of fulfillment, Anderson (1998) maintains that self-assessment is a tool that can affect our pedagogical practices. He is of the view that self-assessment is the only alternative way to shift our focus from traditional or static assessment methods and take a more student-centered approach towards the assessment in classroom.

The last decade has seen the emergence of self-assessment and peer assessment in the domain of education. These new techniques have widely acknowledged for their ability to offer learners new opportunities of learning new forms of a language in classroom environment (Hargreaves, Earl, \& Schmidt, 2001; Esfandiari \& Myford, 2013). These newly emerged assessment tools have developed their frameworks that keep learners at their center. More recently, peer assessment is seen as a great example of a learner-centered learning and evaluation (Birjandi \& Hadidi, 2012), which allows learners to look into their peers' performance. This is considered a reciprocal process that engages the students of a target language to assess each other and learn from each other. This learner-centered approach led to the development of self-assessment technique, which shows that language learners should know about their existing linguistic capabilities, their learning progress, their strengths and weaknesses in a classroom environment. Oscarson and Apelgren (2011) have precisely concluded that in language education of 21 st century, language learners should have the right to monitor their language learning progress.

As the learning outcomes of the students is the key goal of the educational organization, new or alternative ways of assessment is the need of the hour as the traditional assessment tools do not yield the desired results. As part of the alternative assessment, peer assessment and self-assessment have taken over traditional assessment tools which guarantee increased learners' interest, learners' autonomy and increased outcomes for students (Birjandi \& Hadidi, 2012). Birjandi and Sayyari (2010) also state that peer assessment and self-assessment are two pivotal ways of achieving the objectives of educational assessment and learner-centered education. Although the significance of self-assessment is widely acknowledged in different educational contexts, students usually do not get a chance to evaluate their own performance 
(Luoma \& Tarnanen, 2003) as the educational systems still continue to stick to the traditional assessment.

\section{Self-assessment in English Language Teaching}

Self-assessment is commonly used in language teaching context which aims to provide learners with opportunities of evaluating their own progress. The published literature on self-assessment is mainly available in the form of literature reviews and meta-analysis (Andrade \& Valtcheva, 2009; Dochy et al., 1999, Geesline, 2003). More recently, empirical studies focused on evaluating the suitability and effectiveness of self-assessment in order to motivate learners and optimize their learning potential (e.g. Mican \& Medina, 2015; Nguyen et al., 2016; Andrade et al., 2009; Dochy et al., 1999; Geeslin, 2003; Mican, 2015). In terms of reading skills Nguyen, Janssen, Rijlaarsdam, and Admiraal (2016) in their experimental study established that self-assessment on learners' reading tasks can enhance their awareness of their reading skills.

Self-assessment allows learners to evaluate their own performance by reflecting up their strengths and weaknesses to achieve their learning goals and objectives (North Carolina State Department, 1999). Boud and Falchikov (1989) define self- assessment as "the involvement of learners in making judgments about their own learning, particularly about their achievements and the outcomes of their learning" (p. 529). More precisely, if is considered as a formative tool (Falchikov, 2005; Geeslin, 2003) that offers students opportunities to recognize their learning progress and pay heed to those areas of their language performance which require improvement. The process of self-assessment encourages learners' involvement; however, they do not become graders of their own language (Moheidat \& Baniabdelrahman, 2011). In fact, it is a reflective practice that motivates learners to assess their language proficiency. Since it is a great way to encourage learner autonomy, teachers often apply this technique and expect their learners to explore "what is missing on their own, figure out what to do next, and then take responsibility for following through on next steps" (Organization for Economic Co-Operation and Development [OECD], 2005, p. 65).

The practice of self-assessment is not novel to the field of EFL and it is used in different EFL contexts as the "procedures by which the learners themselves evaluate their language skills and knowledge" (Bailey, 1998, p. 227). It is applied and realized in different forms and compositions, such as learners' individual tasks and learners' participation and portfolio (Geeslin, 2003). A large variety of techniques, such as rubrics, checklist, reflective exercises are mixed up and applied by teachers to match the level, age and ability of language learners.

\section{Conclusion}

This paper has reviewed literature on the notion of assessment. As the meaning and significance of assessment have been recognized in the first part of the article, it has described the traditional or static assessment in educational contexts. The article has reviewed studies which show that assessment is an integral part of teaching and learning. Although literature has identified various issues with traditional assessment, it is still a common practice in most of the institutions around the world. The article suggests an alternative 
assessment in the form of authentic and dynamic assessment tools and peer and self-assessment. The reviewed literature argues that traditional assessment cannot help students realize their learning goals and teachers need to adopt alternative assessment tools in order to optimize their learning goals. To achieve these goals, the article has identified various assessment methods, such as authentic assessment, dynamic assessment, peer assessment, and self-assessment. These different forms of assessment provide learners with an opportunity to reflect on their strengths and weaknesses and link them to their future learning goals. The most common of the assessment methods that encourage learners' revision are peer assessment and self-assessment which involve learners to assess their own progress as well as engage with their peers in classroom and give each other feedback on their work. The studies reviewed in this article show that alternative assessment in the form of peer and self-assessment have a positive influence on the language learners' performance and their learning outcomes. Future research on the notion of assessment should focus on the effectiveness of peer and self-assessment in EFL contexts. More importantly, researchers should focus on how learners develop their four language skills with the help of self-assessment and peer assessment in a language classroom.

\section{References}

Aeginitou, V., Nteliou, E., \& Vlahoyanni, N. (2007). Reflections in the mirror: The contribution of self and peer assessment in the teaching of speaking skills. Retrieved from http://my.enl.auth.gr/gala/ppts/aeginitou.ppt

Allan, D. (1999). Testing and Assessment. English Teaching Professional, 11, 19-20.

Anderson, R. S. (1998). Why talk about different ways to grade? The shift from traditional assessment to alternative assessment. New Directions for Teaching and Learning, 74, 5-16.

Andrade, H., \& Valtcheva, A. (2009). Promoting learning and achievement through self assessment. Theory into Practice, 48(1), 12-19.

Anıl, D., \& Acar, M. (2008). Sınıf öğretmenlerinin ölçme değerlendirme sürecinde karşılaştıkları sorunlara ilişsin görüşleri. Yüzüncü Yıl Üniversitesi Eğitim Fakültesi Dergisi, 5(11), 44-66. https://doi.org/10.14527/ pegegog.2014.006

Bailey, K. (1996). Working for washback: A review of the washback concept in language testing. Language Testing, 13(3), 257-279.

Bailey, K. M. (1998). Learning about language assessment. Cambridge, MA.

Berry, R. A. (2010). Preservice and early career teachers' attitudes toward inclusion, instructional accommodations and fairness: three profiles. The Teacher Educator, 45(2), 75-95. https://doi.org/10.1080/08878731003623677

Birjandi, P., \& Hadidi Tamjid, N. (2012). The role of self-, peer and teacher assessment in promoting Iranian EFL learners' writing performance. Assessment \& Evaluation in Higher Education, 37, 513-533. 


\section{Al Macrothink}

International Journal of Linguistics

ISSN 1948-5425

2020, Vol. 12, No. 5

Birjandi, P., \& Siyyari, M. (2010). Self-assessment and Peer-assessment: A Comparative Study of Their Effect on Writing Performance and Rating Accuracy. Iranian Journal of Applied Linguistics, 13(1), 23-45. Retrieved from http://www.academia.edu/464232/Selfassessment_and_Peerassessment_A_ComparativeStud y_of_Their_Effect_on_Writing_Performance_and_Rating_Accuracy

Black, P., \& William, D. (1998). Inside the Black Box: Raising standards through classroom assessment. Granada Learning.

Blanche, P., \& Merino, B. J. (1989). Self-assessment of foreign-language skills: Implications for teachers and researchers. Language Learning, 39(3), 313-338.

Boud, D., \& Falchikov, N. (1989). Quantitative studies of self-assessment in higher education: A critical analysis of findings. Higher Education, 18, 529-549. https://doi.org/10.1007/BF00138746

Brown, H. D., \& Abeywickrama, P. (2010). Language Assessment: Principles and Classroom Practices. White Plains, NY: Pearson Education, Inc.

Brualdi, A. C. (1996). Multiple Intelligences: Gardner's theory, ERIC, Clearing house on Assessment and Evaluation. Washington, DC.

Butt, G. (2010). Making Assessment Matter. London: Continuum International Publishing Group.

Büyüktokatlı, N., \& Bayraktar, Ş. (2014). Fen eğitiminde alternatif ölçme değerlendirme uygulamaları. Pegem Ĕgitim ve Öğretim Dergisi, 4(1), 103-126. https://doi.org/10.14527/pegegog.2014.006

Chen, Y. M. (2008). Learning to self-assess oral performance in English: A longitudinal case study. Language Teaching Research, 12, 235-262.

Cheng, W., \& Warren, M. (2005). Peer assessment of language proficiency. Language Testing, 22(1), 93-121.

Claxton, G. (1995). What Kind of Learning Does Self-assessment Drive? Developing a 'nose' for quality: comments on Klenowski. Assessment in Education, 2(3), 339-343.

Coronado-Aliegro, J. (2006). The effect of self-assessment on the self-efficacy of students studying Spanish as a foreign language. Unpublished Doctoral dissertation, University of Pittsburgh.

Cowie, B., \& Bell, B. (1999). A Model of Formative Assessment in Science Education. Assessment in Education: Principles, Policy \& Practice, 6(1), 101-116. https://doi.org/10.1080/09695949993026

DelliCarpini, M. (2009). Success with ELLs: Authentic assessment for ELLs in the ELA classroom. The English Journal, 98(5), 116-119.

Dickins, R., \& Germaine, K. (1992). Evaluation. Oxford University Press. 


\section{Macrothink}

International Journal of Linguistics

ISSN 1948-5425

2020, Vol. 12, No. 5

Dickinson, L. (1987). Self-instruction in language learning. London: Cambridge University Press.

Dochy, F., Segers, M., \& Sluijsmans, D. (1999). The use of self-, peer, and co-assessment in higher education: A review. Studies in Higher Education, 24(3), 331-350.

Douglas, D. (2010). Understanding Language Testing. London: Hodder Education.

Ekbatani, G., \& Pierson, H. (2000). Learner-Directed Assessment in ESL. Mahwah. NJ: Lawrence Erlbaum Associates.

El Jawhari, M., \& Inspector, F. (1988). Self-assessment in language learning. In Proceedings of the eighth national conference (pp. 35-39).

Esfandiari, R., \& Myford, C. (2013). Severity differences among self-assessors, peer-assessors, and teacher assessors rating EFL essays. Assessing Writing, 18, 111-131.

Falchikov, N. (2005). Improving Assessment through Student Involvement: Practical Solutions for Aiding Learning in Higher and Further Education. Oxon: Routledge Falmer.

Falchikov, N., \& Goldfinch, J. (2000). Student peer assessment in higher education: A meta analysis comparing peer and teacher marks. Review of Educational Research, 70(3), 287-322.

French, D. (2003). A new vision of authentic assessment to overcome the flaws in high stakes testing. Middle School Journal, 35(1), 14-23.

Gardner, D. (1999, May). Self-assessment for self-access language learners. Paper presented at the workshop entitled Accessing self-access: Practical discussions and workshops, English Centre, Hong Kung University, Hong Kung. Retrieved from http://www.cityu.edu.hk/elc/HASALD/meeting/99workshop/workshop99davidgardner.m

Geeslin, K. L. (2003). Student self-assessment in the foreign language classroom: The place of authentic assessment instruments in the Spanish language classroom. Hispania, 86(4), 857-868.

Hamed, J. J. (2012). The Effect of Peer Reviewing on Writing Apprehension and Essay Writing Ability of Prospective EFL Teachers. Australian Journal of Teacher Education, 37(11), 59-84. Retrieved from http://ro.ecu.edu.au/ajte/vol37/iss11/4

Hargreaves, A., Earl, L., \& Schmidt, M. (2001). Perspectives on alternative assessment reform. American Educational Research Journal, 39, 69-95.

Haywood, H. C., \& Lidz, C. S. (2007). Dynamic assessment in practice: Clinical and educational applications. Cambridge: Cambridge University Press.

Heinle, H., Baleghizadeh, S., \& Masoun, A. (2013). The effect of self -assessment on EFL learners' selfefficacy. TESL Canada Journal, 31(1), 42-58.

Huerta-Macias, A. (1995). Alternative assessment: Response to commonly asked questions. TESOL Journal, 5, 8-11. 
Judy, S., Crick, D., Yu, G., Lawson, H., Harlen, W., \& Durant, K. (2008). Systematic review of research evidence of the impact on students in secondary schools of self and peer assessment. London: EPPI-Centre, Social Science Research Unit, Institute of Education, University of London. Retrieved from http://eppi.ioe.ac.uk/cms/Default.aspx?tabid=2415

Kavaliauskienè, G. (2007). Students' reflections on learning English for specific purposes. English for Specific Purposes World Online Journal for Teachers. Retrieved from http://www.espworld.info/Articles_15/ESP_REFLECTIONS_ON_LEARNING.htm

Kırmızı, Ö., \& Kömeç, F. (2016). An Investigation of Performance-Based Assessment at High Schools. Üniversitepark Bülten, 5(1-2), 53-65. https://doi.org/10.22521/unibulletin.2016.512.5

Kozulin, A., \& Garb, E. (2002). Dynamic assessment of EFL text comprehension of at-risk students. School Psychology International, 23(1), 112-127.

Lambert, D., \& Lines, D. (2000). Understanding Assessment: Purposes, Perceptions, Practices. London, Routledge Falmer.

Lenski, S. D., Ehlers-Zavala, F., Daniel, M. C., \& Sun-Irminger, X. (2006). Assessing English language learners in mainstream classrooms. The Reading Teacher, 60(1), 24-34.

Leung, C. (2007). Dynamic assessment: Assessment for and as teaching? Language Assessment Quarterly, 4(3), 257-278.

Lidz, C. S., \& Elliott, J. G. (2000). Introduction. In C. S. Lidz, \& J. G. Elliott (Eds.), Dynamic assessment: Prevailing models and applications (pp. 3-13). Amsterdam: Elsevier.

Lin, Z. (2010). Interactive dynamic assessment with children learning EFL in kindergarten. Early Childhood Education Journal, 37, 279-287.

Luoma, S., \& Tarnanen, M. (2003). Creating a self-rating instrument for second language writing: From idea to implementation. Language Testing, 20, 440-465.

Martin, R. (2008). Using the common European framework for self-Assessment in EFL classes. Proceedings of 25th International Conference of English Teaching and Learning: International Conference on English Instruction and Assessment (pp.1-8). Retrieved from http://www.ccu.edu.tw/fllcccu/2008EIA/zh/C32.pdf

Matsuno, S. (2009). Self-, peer-, and teacher-assessments in Japanese university EFL writing classrooms. Language Testing, 26, 75-100.

McNamara, T. (2004). Language testing. In A. Davies, \& C. Elder (Eds.), The handbook of applied linguistics (pp. 763-783). Malden, MA: Blackwell.

Mican, A. D., \& Medina, L. C. (2015). Boosting vocabulary learning through self-assessment in an English language teaching context. Assessment \& Evaluation in Higher Education, 42(3), $1-15$.

Moheidat, A. S., \& Baniabdelrahman, A. A. (2011). The impact of Omani twelfth-grade students' self-assessment on their performance in reading in English. Asian EFL Journal, 13(1), 48-84. 
Montgomery, K. (2002). Authentic tasks and rubrics: Going beyond traditional assessments in college teaching. College Teaching, 50(1), 34-39.

Murphy, A. F. (2009). Tracking the progress of English language learners. The Phi Delta Kappa International, 91(3), 25-31.

Nguyen, P. N. T., Janssen, T., \& Rijlaarsdam, G. (2016). Effects of self-questioning on EFL students' engagement in literary reading. Culture and Education, 28(4), 702-737.

North Carolina State Department of Public Instruction. (1999). Assessment articulation, and accountability, 1999: A foreign language project. Raleigh, NC.

O’Malley, J. M., \& Pierce, L. V. (1996). Authentic assessment for English language learners: practical approaches for teachers. New York: Addison-Wesley Publishing Company, Inc.

Oscarson, M., \& Apelgren, B. M. (2011). Mapping language teachers' conceptions of student assessment procedures in relation to grading: A two-stage empirical inquiry. System, 39, 2-16.

Paris, S. G., \& Paris, A. H. (2001). Classroom applications of research on self-regulated learning. Educational Psychologist, 36(2), 89-101.

Poehner, M. E. (2007). Beyond the test: L2 dynamic assessment and the transcendence of mediated learning. The Modern Language Journal, 91, 323-340.

Poehner, M. E. (2008). Dynamic assessment: A Vygotskian approach to understanding and promoting L2 development issues and implications. University Park, PA: Springer.

Popham, W. J. (1997). What's wrong-and what's right-with rubrics. Educational Leadership, $55,72-75$.

Richards, J. C., \& Renandya, W. A. (2002). Methodology in language teaching: An anthology of current practice. Cambridge University Press. https://doi.org/10.1017/CBO9780511667190

Richards, J. C., \& Schmidt, R. W. (1985). Longman dictionary of language teaching and applied linguistics. Routledge.

Sarıçoban, A. (2011). A Study on the English language teachers' preparations of tests. Hacettepe Universitesi Eğitim Fakültesi Dergisi, 41(41), 398-410.

Srichanyachon, N. (2011). A comparative study of three revision methods in EFL writing. Journal of College Teaching and Learning, 8(9), 1-8.

Stiggins, R. J. (2002). Assessment Crisis: The Absence of Assessment for Learning. Phi-Delta Kappan, 83(10), 758-765. https://doi.org/10.1177/003172170208301010

Tan, H. K. (2008). Qualitatively different ways of experiencing student self-assessment. Higher Education Research \& Development, 27(1), 15-29. Retrieved from http://www.informaworld.com/10.1080/07294360701658708

Taras, M. (2005). Assessment- summative and formative-some theoretical reflections. British Journal of Educational Studies, $\quad$ 53(4), https://doi.org/10.1111/j.14678527.2005.00307.x 


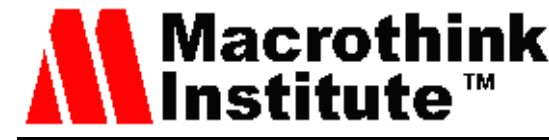

International Journal of Linguistics

ISSN 1948-5425

2020, Vol. 12, No. 5

Topping, K. (2003). Self and peer assessment in school and university: Reliability, Validity, Utility. In M. Segers, J. R. C. Filip, \& D. E. Cascallar (Eds.), Optimizing New Modes of Assessment: In Search of Qualities and Standards. Kluwer Academic Publishers.

Topping, K. (2009). Peer assessment. Theory into Practice, 48(1), 20-27.

Topping, K., Smith, F. F., Swanson, I., \& Elliot, A. (2000). Formative peer assessment of academic writing between postgraduate students. Assessment and Evaluation in Higher Education, 25(2), 149-169. https://doi.org/10.1080/713611428

Valeri-Gold, M., Olson, J. R., \& Denning, M. P. (1992). Portfolios: Collaborative authentic assessment opportunities for college developmental learners. Journal of Reading, 35(4), 298-305.

Wang, K. H., Wang, T. H., Wang, W. L., \& Huang, S. C. (2006). Learning styles and formative assessment strategy: enhancing student achievement in Web-based learning. Journal of Computer $\quad$ Assisted 207-217. https://doi.org/10.1111/j.13652729.2006.00166.x

Watering, G., Gijbels, D., Dochy, F., \& Rijt, J. (2008). Students' Assessment Preferences, Perceptions of Assessment and Their Relationships to Study Results. High Education, 56, 645-658. https://doi.org/10.1007/s10734-008-9116-6

Wei, Y., \& Chen, Y. (2004). Supporting chinese learners of English to implement self-assessment in L2 writing. Proceedings of the Independent Learning Conference.

White, E. (2009). Student Perspectives of Peer Assessment for Learning in a Public Speaking Course. Asian EFL Journal, 33(1), 1-55.

Wojtczak, A. (2002). Medical Education Terminology. Medical Teacher, 24(4), 357-357. https://doi.org/10.1080/01421590220145699

Yuji, N. (2002). Teacher assessment and peer assessment in practice. Educational Studies, 44, 203-215.

Zavistanaviciene, D., Nedzinskaitè, I., \& Švenčionien, D. (2006). Achievements in language learning through students' self-assessment. Studies About Languages, 84-87. Retrieved from http://www.ceeol.com

\section{Copyrights}

Copyright for this article is retained by the author(s), with first publication rights granted to the journal.

This is an open-access article distributed under the terms and conditions of the Creative Commons Attribution license (http://creativecommons.org/licenses/by/4.0/) 